\section{In search of the insoluble}

\section{Eric Ashby}

The Youngest Science: Notes of a

Medicine-Watcher

By Lewis Thomas.

Viking: 1983. Pp.266. \$14.75.

NEARLY 60 years ago I enrolled as an undergraduate at the Imperial College in London. I had to pick a subject subsidiary to my main subject and chose botany because I had never even read anything about it. The elementary lectures were given by the head of the department, J.B. Farmer. His lectures so fascinated me that I switched subjects and graduated in botany.

The point of this lapse into autobiography is to confess that in 1923 it wasn't the content of botany that attracted me: it was the way Farmer taught it. Samuel Alexander once wrote that "liberality is a spirit of pursuit, not a choice of subject". It was Farmer's "spirit of pursuit" that caught my imagination. He would be talking about the anatomy of desert plants and suddenly illuminate it with hexameters from Lucretius. From pollination mechanisms he led us to reflect on teleology by way of Aristotle and St Thomas and brought us safely back to neoDarwinism. What appeared in the College calendar merely as "Botany I" was an unforgettable intellectual experience.

Few teachers have this rare gift. Lewis Thomas, a distinguished medical biologist, is one of them. He was asked to write some light-hearted essays for the New England Journal of Medicine (the essays, collected in book form as The Lives of a Cell and The Medusa and the Snail, were reviewed in Nature 258, 24 (1975) and 282, 140 (1979)). He may have intended the essays simply to provide entertainment for medicals. Like Farmer's Botany I, they go far beyond their intention. There is a nice passage in The Youngest Science where Thomas tells how he was able to examine the inside of his intestine with a colonoscope. To read his essays is to perform a kind of endoscopy on his mind. They show how some biological event stimulates a whimsical curiosity which grows into wonder and then into a dogged determination to understand. I hazard a guess (Thomas will not mind: he is hazarding guesses all the time in this book) that mycoplasmas appeal to that same region of his mind as Mozart quartets do.

In this book Thomas reflects on episodes in his own scientific career, reminiscences of the kind you might persuade him to talk about in a long summer evening after dinner. His father was a general practitioner, working from home without a nurse or a secretary, in a small country town where patients were treated as people and not clinical material. And this leads Thomas to think about the way modern medical technology has separated the doctor from the patient, and what a pity this is. For the best medicine the doctor can give for many ailments is a dose of confidence; and that is best administered when the doctor touches the patient. Before the invention of the stethoscope the doctor would put his ear against the patient's heart and chest. The stethoscope came into use,

vastly enhancing the acoustics of the thorax, but removing the physician a certain distance from his patient. It was the earliest device of many still to come . . . designed to increase that distance. This is no atavistic harking back to the prescientific days of medical practice; it is a reminder that although medicine is the "youngest science" and has a dazzling record of achievement, nevertheless there is still much more than science in the treatment of sickness. "If I were a medical student" he says,

I would be more worried about this aspect of my future than anything else. I would be apprehensive that my real job, caring for sick people, might soon be taken away, leaving me with the quite different operation of looking after machines.

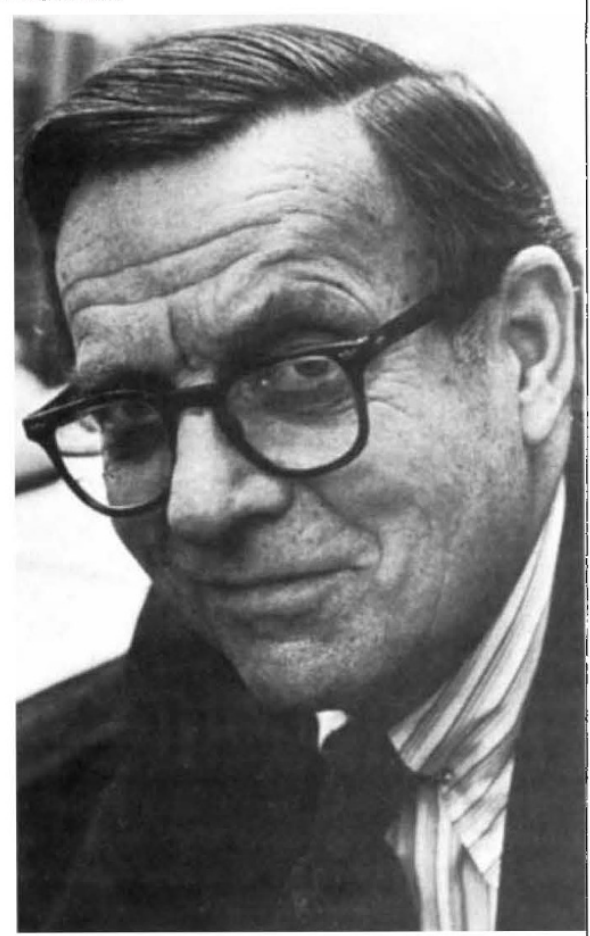

Lewis Thomas, "still at work and ready to create insoluble problems if he should ever run short of them"'

But Thomas, though he has done much caring for patients in his time, has been compelled, by his inordinate curiosity, to spend most of his career doing research. So the after-dinner talk turns to his war service in Guam and Okinawa. He was sent to deal, among other things, with scrub typhus, but in the event there was no scrub typhus in Okinawa. That meant that he and his colleague were (as he put it) "effectively out of business from the outset". What were they to do with the colony of mice they had brought with them, bedded down under the bunk in reams of toilet paper? Business soon revived: there was a nasty outbreak of encephalitis. Within a week they had the virus reproducing the disease in mice.

And after the war was over? Thomas wanted what most of us wanted: an opportunity to settle down to ten, twenty, years of productive work. He got it. After two short spells, one in Baltimore and one in New Orleans, he was invited to a chair of pediatrics and medicine in the University of Minnesota. It was just what he wanted: the city, the symphony orchestra, a newly constructed hospital, lively colleagues. "It was the greatest fun, and I thought we would stay there for ever."

But, like a rapidly growing plant, Thomas needed to be re-potted regularly. Four years later he was told he was on the search-committee's list for the chairmanship of the pathology department in the New York University College of Medicine. Would he be interested? His reply tells us a lot about his intellectual ebullience: "if they get down to my name, I'll come in a minute". And it tells us how, despite his successful research career, he had never deviated far from the compassionate interest in patients that his father had had; for a little later he became chairman of the medical division in the Bellevue Hospital,

an ancient set of buildings beginning to fall apart, long open wards filled with the sickest and poorest of New York's citizens, inadequately supported by the city but obliged . . . to take all patients who came to its doors.

His loving but frank account of the hospital is a grim portrait of the attitude to health-care in one of the richest cities on Earth. It provided the "best of all possible medical care for the sickest of patients under the worst of conditions". Every item of supply, from penicillin to toilet paper, in short supply or lacking altogether. Everything - beds, wheelchairs, radiators, windows, elevators, needed repairing. Thomas eagerly accepted the challenge and found himself up against the Byzantine fiscal functionaries in City Hall. A fresh type of problem, but he tackled it with the debonair enthusiasm he brought to the study of endotoxin. ("The key to a long, contented life in the laboratory is to have a chronic insoluble problem and keep working at it.")

Now, as chancellor of the Memorial Sloan-Kettering Cancer Center in New York, Thomas is still at work, ready to create insoluble problems if he should ever run short of them. He would regard The Youngest Science as a slight piece of work, as indeed it is compared with his papers on endotoxins, mycoplasma infection and immunology. But the book explains, more vividly than any of the scientific papers could explain, just how those papers came to be written, and what it is like to be a medical biologist.

Lord Ashby is a Fellow of Clare College, Cam bridge, and author of The Search for an Environmental Ethic, in Vol. 1 of the Tanner Lectures published by the Utah and Cambridge University Presses in 1980. 